\title{
BANKING SYSTEM FAILURES IN DEVELOPING AND TRANSITION COUNTRIES: DIAGNOSIS AND PREDICTION
}

by

Patrick Honohan

January 1997

BANK FOR INTERNATIONAL SETTLEMENTS

Monetary and Economic Department

BASLE 
BIS Working Papers are written by members of the Monetary and Economic Department of the Bank for International Settlements and published by the Bank. The papers are on subjects of topical interest and are technical in character. The views expressed in them are those of their authors and not necessarily the views of the BIS.

(C) Bank for International Settlements 1997

CH-4002 Basle, Switzerland

Also available on the BIS World Wide Web site (http://www.bis.org).

All rights reserved. Brief excerpts may be reproduced or translated provided the source is stated.

ISSN 1020-0959 


\title{
BANKING SYSTEM FAILURES IN DEVELOPING AND TRANSITION COUNTRIES: DIAGNOSIS AND PREDICTION
}

by

\author{
Patrick Honohan*
}

January 1997

\begin{abstract}
Understanding what caused the recent costly wave of banking system failures in developing and transition economies is the key to preventing a recurrence. It is important to distinguish between epidemics of the macroeconomic and microeconomic varieties, and between these and the syndrome of endemic failure, associated with pervasive government involvement. Each type has its characteristic warning signs - the availability of the relevant indicators is discussed in some detail - and a comprehensive prevention policy must take account of each.

Thus, for example, it is unwise to defer macroeconomic stabilisation in the hope of concealing banking sector weakness. Likewise, a rigorous application to developing and transition economies of the consensus approach to microeconomic regulation should not be deferred. Political interference is the Achilles heel of any regulatory system: among other mechanisms, it may be possible to use disclosure rules and the pressures of globalisation to increase the political attraction of regulatory enforcement.
\end{abstract}

* The author is a research professor at the Economic and Social Research Institute, Dublin and a research fellow at the Centre for Economic Policy Research, London. Much of the underlying research was carried out while the author was a visiting scholar at the Research Department of the International Monetary Fund. He is indebted to Philip Berlin, Jerry Caprio, David Folkerts-Landau, Gillian Garcia, Philip Turner and Dimitri Vittas for helpful comments. 



\section{Contents}

Introduction and summary

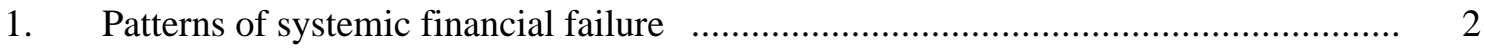

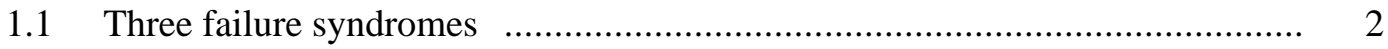

1.1.1 The macroeconomic epidemics ......................................................... 2

1.1.2 Poor management and other microeconomic deficiencies ................... 4

1.1.3 Endemic crisis in a government-permeated banking system $\ldots . . . \ldots \ldots \ldots \ldots . . . . . \quad 7$

1.2. Evolution of the crisis: the role of regime changes f..................................... 10

1.2.1 Financial repression ..................................................................... 11

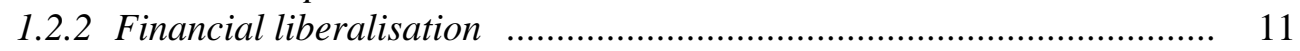

1.2.3 Macroeconomic instability ........................................................... 12

1.2.4 Structural economic transformation ............................................... 12

1.2.5 Political developments ...................................................... 13

1.2.6 Privatisation ..................................................................... 13

1.2.7 Technological innovation and globalisation in finance ...................... 13

2. Collecting data for early warning ............................................................................. 14

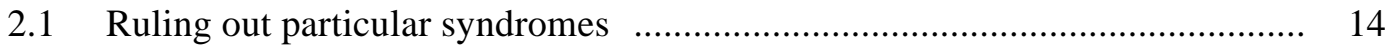

2.2 The structural indicators …................................................................... 14

2.2.1 Indicators for macroeconomic epidemics .......................................... 15

2.2.2 Indicators of poor management and other microeconomic deficiencies .................................................................................. 15

2.2.3 Indicators of a government-permeated banking system ..................... 17

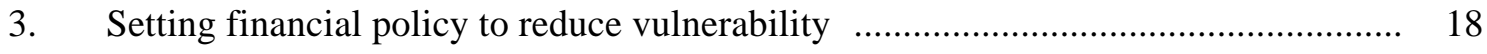

3.1 Macroeconomic and banking system stability ........................................... 18

3.2 Building a robust regulatory system: consensus on most technicalities $\ldots \ldots \ldots . . .19$

3.2.1 The consensus ............................................................................. 19

3.2.2 Design of regulation: some adaptations needed for developing

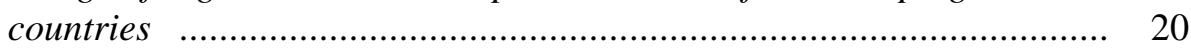

3.2.3 Speed limits .............................................................................. 21

3.3 Political obstacles to effective regulation f..................................................... 21

3.3.1 Deposit insurance and the narrow bank ........................................... 22

3.3.2 Disclosure ............................................................................... 23

3.4 Positive aspects of international financial integration ................................... 24

3.4.1 Can internationalisation provide insulation? ..................................... 24

3.4.2 An international seal of approval ................................................... 25

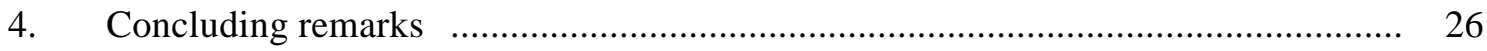

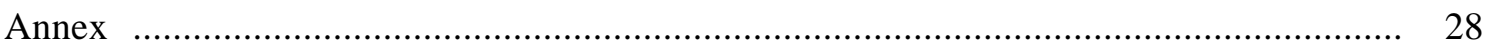

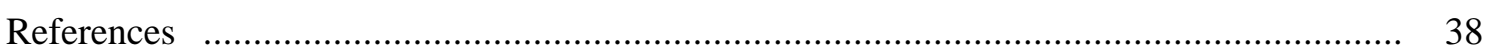





\section{Introduction and summary}

The prevalence of financial system failures has been at least as great in developing and transition countries as in the industrial world. Resolution costs in the order of \$250 billion in these countries have been incurred. These costs have partly been borne by depositors and other creditors of failed banks, but it is largely governments which have, in one way or another, footed the bill. ${ }^{1}$

Although some of the costs are more in the nature of transfers than pure economic losses, the magnitude of the problem cannot really be doubted. It reflects a waste of investible resources in countries where both the potential productivity of capital and the need for sound credit decisions are great. Furthermore, the assumption by government of large and unforeseen bailout costs can destabilise programmes of fiscal consolidation as well as adding to the deadweight cost of taxation.

No doubt lessons have been learnt, and some mistakes that have led to bank failures may be avoided in future. But the way in which patterns of systemic financial failure have recurred around the world in recent years gives cause for concern that the current wave of crises may not yet be drawing to a close, and that it may soon be succeeded by another wave.

Isolated bank failures are inevitable, and it would be unwise to aim for zero tolerance. What can be avoided is widespread systemic failure, where a large part of the banking system is paralysed. Section 1 of the paper reviews recent experience in the developing and transitional world. Widespread failures have usually occurred during a period of increased vulnerability that can be traced back to some regime change, induced by policy or by external conditions. Though systemic crises display some common features across countries, a small number of contrasting types can be distinguished. In order to help forestall future systemic crises, it is necessary to be aware of these different patterns. We describe the contrast between epidemics of the macroeconomic and microeconomic varieties, and between these and the syndrome of endemic failure, typically associated with pervasive government involvement in the banking system. It is the first, macroeconomic, type that has been most familiar in the industrial world, but the others have been more common in developing and transition economies.

Knowing the types of crisis that can occur, and alert to regime changes that can heighten vulnerability, we should be better placed to have early warning of crises. Section 2 discusses quantifiable indicators, some of which are already available, and others which could quite easily be collected, perhaps by an international organisation, and sifted for advance indications of imminent crisis.

1 Recent cross-country surveys include BIS (1996), Caprio and Klingebiel (1996), Lindgren et al. (1996). 
Section 3 turns to the question of prevention. Macroeconomic stabilisation policy is important for maintaining financial sector health, and should not be derailed by a short-term fear of revealing financial sector weakness. An energetic theoretical debate about refinements should not be allowed to conceal the broad consensus that exists on the regulatory structures required for limiting microeconomic weaknesses, though some quantitative adaptation is required for developing and transition economies. Among possible refinements, the idea of "speed limits" is the least problematic. Political interference is the Achilles' heel of any regulatory system. In order to enhance the political attraction of regulatory enforcement, we consider the options of "narrow banking" and of greater disclosure.

Often thought of as a threat, increased globalisation can also be turned to advantage, with increased ownership links potentially strengthening the resilience of a small economy's banking system. An international seal of approval, whether from private rating agencies, or through a new public collaborative initiative, also offers favourable prospects.

\section{Patterns of systemic financial failure}

\subsection{Three failure syndromes}

Systemic failures in the financial system are typically complex and they differ one from the other. In order to understand the processes involved it is necessary to schematise and simplify, but extreme reductionism is misleading. As the causal mechanisms are not fully understood, it is unwise to rely on a classification by supposed cause. Instead, as is done with diseases which are not well understood, we can classify by the characteristic group of symptoms displayed - the syndrome.

Many banking system crises in developing countries seem endemic, displaying a recurrent pattern of distress with insolvency and illiquidity (usually traceable to pervasive government involvement) persisting for years. Other countries have experienced epidemics, sometimes involving macroeconomic collapses, sometimes not. Each of these three categories shares some symptoms with the others, but a review of the characteristics of a large number of developing country cases suggests that the three syndromes are distinctive. The search for warning signals and prevention mechanisms needs to take this into account.

\subsubsection{The macroeconomic epidemics}

The degree to which financial systems can absorb macroeconomic shocks without suffering institutional failure obviously varies enormously. But some banks survive even very severe macroeconomic shocks, suggesting that other banks could have too, had they followed policies designed to insulate themselves from disturbance. By the same token, one must be sceptical of 
assertions that a banking system has collapsed because of a macroeconomic shock. Some banking systems have survived very severe macroeconomic shocks. ${ }^{2}$

The more interesting cases are what we may call endogenous macroeconomic disturbances, and specifically an endogenous boom and bust cycle, where banks, riding on a wave of optimism, overlend to projects which have poor long-term prospects. The very process of lending contributes to the temporary success of these projects as borrowers bid up the price of land and other property, and as wealth effects on consumption raise the profitability of most economic activities.

Thus, in contrast with the other cases to be considered, the role of macroeconomic fluctuations here is not simply to act as a trigger which will reveal the underlying weakness of the banking system. Instead, the banking system's behaviour (especially over-optimistic lending decisions) itself amplifies the upturn, thereby increasing the share of lending based on unrealistic prices and price trends. When the bubble bursts, the banking system is coping with a macroeconomic downturn which, at least to a degree, is of its own making.

Widely discussed in the 1930s, this endogenous boom and bust story became relevant again with the correlated experiences of Argentina, Chile and Uruguay in 1979-83, and subsequently with the Nordic banking crisis of 1987-94 and that of Japan since 1992. The case of Mexico in 1994 is also relevant. At the international level, the boom in lending to developing countries in the late 1970s and until it burst in 1982 has important points of similarity.

This type is really a hybrid of macro and micro causes. In order for the endogenous boom to take place, there certainly need to be microeconomic deficiencies in bank behaviour, as well as errors in macroeconomic or monetary policy management.

On the micro side, unless the system is very concentrated, no one bank is large enough to generate an asset price boom on its own. Instead, it is frequently observed that bankers "hunt in herds". Such behaviour may be individually rational behaviour, for example if each banker is attempting either to learn by observing the behaviour of others, or to avoid criticism (from senior management, from shareholders, from regulators) by adopting market norms for lending. A shift in bank views on sectoral creditworthiness may be temporarily self-fulfilling, especially in sectors such as property, where the weight of money lent may drive up the asset price thereby generating further demand from beneficiaries or would-be beneficiaries of the boom. Lending to support speculative purchases on the stock market can also work in this way, whereas lending for manufacturing, agriculture or consumer durable purchases is less likely to have strong asset price effects. ${ }^{3}$

2 An exception may be made for war. The collapse of banking systems in Liberia, Lebanon and Kuwait (1990-91) need not be attributed to deficient banking practices. Likewise the political crisis in Panama in 1988-89 may be considered so severe as to have outstripped the resources of even the most conservatively managed banking system.

3 Note that this kind of "weight of money" reasoning differs substantially from the textbook model of asset pricing, where the capitalisation of expected future dividend or rental streams is held to anchor the market price of an asset. Anything else represents a bubble whose rationality can rarely be justified. Thus microeconomic deficiencies on the part of borrowers are also present. 
Some other micro-markers of bad banking will also be present, such as self-lending (for who would want to forgo the benefit of the asset price boom?) and excessive risk-taking through the use of leveraged asset price derivatives.

In terms of macroeconomic policy it should be noted that the credit expansion involved in the boom stage of this kind of cycle will in turn require adequate base money in the system. That is why capital inflows are often present at least in the early stages. Ex post appropriate monetary policy would intervene to drain the monetary system of the base money resources needed to support the credit boom. However, this may not be easy, especially if a tightening of monetary conditions increases interest rates, thereby encouraging an acceleration of capital inflows. Besides, monetary authorities focusing on goods price inflation may not attach comparable importance to asset price inflation. But this is the time to remember that the major function of the central banker is to "take away the punchbowl just when the party is getting under way".

The unwinding of this kind of credit-driven boom can be quite sudden. Withdrawal of foreign capital may slow the expansion of credit, thereby halting the property price spiral, and even placing the banks under liquidity pressure. In the circumstances, attempts by the banks to call in loans or to refuse to renew them lead to selling pressure in the asset market which in turn both pushes many of the banks' borrowers into financial distress and reduces the value of the banks' collateral.

Because of the very visible collapse in asset prices, well-founded questions over the viability of the banks will quickly emerge, possibly leading to runs, and an additional twist to the asset price deflation from forced sales, as well as depressed expectations.

Because of the magnitude and dramatic suddenness of these crashes, the story of endogenous boom and bust is sometimes thought of as the archetypical banking crisis (Davis (1992) and Gavin and Hausman (1995)). It is important to recognise that it is less frequent than other types, for if we look only for symptoms of an unsustainable bank-driven boom, we risk ignoring other types of emerging crisis with different characteristics.

\subsubsection{Poor management and other microeconomic deficiencies}

There have also been failure epidemics not strongly associated with macroeconomic collapse. Although much of the "rational expectations" literature rules out systematic management errors, a minority thread points out that this assumption may be over-optimistic (see Arrow (1982) and Guttentag and Herring (1986)). In particular, the comparative rarity of bank failures (even now) means that bank policies for avoiding failure have not been honed on repeated experiences of difficulty. Psychological explanations refer to "disaster myopia" as a phenomenon which induces managers to neglect events which, though large, have only a small probability of occurring and do not readily come to mind as a relevant contingency. 
Evidently, the susceptibility of a financial system to this kind of myopia is increased whenever the environment for banking changes dramatically, as when there is a liberalisation such as the removal of credit ceilings or administrative controls on interest rates, when new entrants have been permitted, or following privatisation (as recently in Mexico). This kind of event increases the volatility of prices facing the market participants and, by increasing competition, may place pressure on the profitability of old-established banks whose cost base had expanded under the protection of the old restrictions.

A review of international experience shows a multitude of cases where the simplest explanation for bank failure is poor management (de Juan (1995)). Some recent examples may be found among newly established banks in transition economies such as Estonia and Lithuania, which have fallen at this hurdle, and the consequences of a rapid increase in the number of banks may be becoming evident in the reported difficulties of Indonesian banks in recent months. For an individual bank, this kind of failure can often be traced to poor lending decisions based on an over-optimistic assessment of creditworthiness, willingness to repay, or the recoverability of delinquent loans; undue concentration of lending in readily available or "hot" sectors, or to particular borrowers; overly rapid credit expansion exceeding the technical capacity of the bank's lending function or (if generalised) even exceeding the economy's potential to generate bankable projects.

A common feature of problems of this sort is self-lending or lending to entities associated with the bank's shareholders or managers. Such lending is tightly constrained by regulation in most countries, but the regulations are frequently evaded, bypassed or waived. Over the years, many banks - even successful ones - have been set up with the idea of providing a convenient and inexpensive form of financing to the founder's enterprises. But if a bank is part of a wider financial-industrial group, it must be at risk unless and until it is seen as a profit centre, rather than a cost centre in the group. It need not be the intention of the group to place the bank at risk, let alone drive it into insolvency, but by substituting a captive bank for the discipline of sourcing funds from independent financiers, the group risks falling prey to over-optimism in its ventures.

Other, non-lending sources of difficulty can also be put down to poor management, including the assumption of risky open foreign exchange positions, adopted to benefit from uncovered interest differentials, as was widespread in Chile, Turkey and Mexico. ${ }^{4}$ Even when the funds are onlent to domestic borrowers in foreign-exchange-denominated loans, the borrowers are often unable to survive a large devaluation, so the foreign exchange risk has not been hedged, just transformed into credit risk.

Modern techniques of bank regulation and supervision are well-adapted to identifying and limiting the effects of management deficiencies of this type. A widespread banking crisis which is

4 In Mexico, highly leveraged open foreign exchange positions were adopted by banks in 1994 for this very reason. Interestingly, the banks used complex derivative instruments which helped them conceal the true nature of the positions from regulators (Garber (1995)). 
attributed to poor management may as well be attributed to poor supervision and enforcement. All too often, the problem is not that the supervisors didn't know or suspect, but that the bank owners were too well-placed politically for their actions to be curtailed by supervisors without the most conclusive of evidence.

It may be asked whether this type of crisis is really systemic, or whether it relates primarily to isolated banks. The experience has been that countries do experience a bunching of similar bank failures. This is mainly because deficiencies at different banks were allowed to deepen under common external conditions, including weak supervision, though failure can propagate from one bank to others through competitive pressures.

\section{Recklessness and fraud}

Both theory and practice confirm that banks' management tends to adopt riskier lending and other strategies than would be socially optimal as a result of the existence of official deposit guarantees, explicit or implicit. Essentially the point is that, in the absence of deposit guarantees, private depositors would require adequate interest remuneration to compensate them for the expected riskiness of the portfolio, and would have to satisfy themselves as to what that level was. The existence of a deposit guarantee removes the depositor's fear of default (at least to some extent), allowing the equity holder to adopt riskier strategies offering a higher return to equity if successful, and without incurring higher interest costs.

A close parallel may be found in the behaviour of dealers in the trading and treasury departments of banks. If these receive huge bonus payments when their trading is successful, and have nothing to lose but their jobs if unsuccessful, the same kind of risk-preferring behaviour is easily explained. Only with adequate controls on risk-taking, including an appropriate structure of rewards, can this problem be kept under control. The 1995 failure of Barings bank is only the most dramatic instance of this type of effect.

A distinction may be drawn between an increase in risk-taking and another possible response to deposit guarantees, namely what has been described as "looting" (Akerlof and Romer (1993)). Looting takes advantage of the fact that sufficient time will elapse between receipt of deposit and failure to allow the management to divert a substantial portion of the funds for its own purposes. In this case the behaviour of the management cannot be adequately captured by the term "risk-taking", as it benefits even if the ventures to which the funds are applied do not repay the bank. An example would be self-lending for an associated property venture which purchases land from the management at an inflated price. Even if the property venture fails, the management has benefited.

Looting behaviour may still be legal, though clearly on the margins of legality. This is one thing that may allow it to continue even if the bank supervisors are aware of, or at least suspect, what is going on. It shades into outright fraud. 
Much has been heard of fraud in recent bank failures. This has always been a problem in banking. The potential for fraud occurs at various levels. Staff fraud is usually on a small scale insufficient to bring down a bank, though the sums transacted by trading desks can be sufficiently large to do so if adequate internal control procedures are not in place. Fraud by management is a different matter. Because of the risk of criminal sanctions, outright fraud by management or shareholders commonly occurs only on a very large scale, or if the bank is already in a parlous situation so that the alternative to looting and fraud is unattractive.

Although fraud tends to be isolated it can occasionally be at the centre of a system-wide crisis. This appears to have been the case in Venezuela (1994). Another instance of systemic fraud is the curious and dramatic case of Guinea in 1985 where the six main banks, accounting for over $95 \%$ of the system, were closed on a single day. According to the account by Tenconi (1988), this was the culmination of widespread bank draft fraud perpetrated by customers (perhaps with the collusion of bank staff).

\subsubsection{Endemic crisis in a government-permeated banking system}

In many countries the role and functioning of the banking sector is intimately linked with the financing of government and on behalf of government. The involvement takes many forms, ranging from government ownership, through programmes of directed lending or investment, to complex and distorting tax and subsidy regimes both explicit and implicit. As a result of these linkages, government policy objectives permeate the activities of banking systems in this condition. Banks are then not autonomous profit-seeking entities, but operate, to a greater or lesser extent, as a quasi-fiscal mechanism, differing from the budget chiefly in the degree to which the funds employed can circulate rather than being an out-and-out grant.

In good times, such banking systems can appear to be functioning without undue problems. Steady economic growth generates growth in deposit liabilities even at low interest rates, and this can fund a steady expansion in borrowings by state-owned enterprises or other favoured borrowers, even where the borrowers would be hard-pressed, if called upon, to repay. Occasional injections of capital funds by the government to support the balance sheet may be represented in a positive fashion.

Even if a relatively high proportion of the borrowers are able and willing to service their bank loans, inadequate loan pricing and provisioning mean that even a small but steady flow of new lending and interest capitalisation to non-performing borrowers results in a gradual erosion of the true capital of such banks to the point where they are actually insolvent in economic terms (present value of liabilities exceeds recoverable value of assets), although perhaps not yet unable to meet cash needs as they arise. 
An adverse shock such as a reduction in the trend of deposits, or an increase in interest rates, is all that is needed to expose the underlying insolvency. Such shocks will typically be systemwide, resulting in the simultaneous emergence of problems in many banks.

Because of increasing awareness of the potential for loan loss problems, tougher loan classification regulations and the intensification of supervision, the poor quality of the portfolios of banks which are thus entangled in the business of lending at the behest of government has become known even without a crisis of liquidity emerging. Audits and reviews carried out under the auspices of the World Bank or Regional Development Banks have often been the vehicle for increased awareness of these problems. Another event triggering exposure of the condition of such banks is a change of government, which removes some of the inhibitions which may have prevented insiders from drawing attention to the relevant facts. This all makes it difficult to date the events that have led to insolvency: banking sector authorities become fully aware of the problems at a more-or-less arbitrary stage in the process.

\section{Quasi-fiscal aspect}

Nevertheless, especially in the case of government-owned development banks, the idea that a proportion of lending would prove irrecoverable may have been implicitly accepted by the fiscal authorities from the start. Lending has been designed to conceal or defer a fiscal problem by making a substandard loan to support a government policy objective. From this point of view, the costs of restructuring or liquidating such banks can be seen as the redemption of a quasi-fiscal liability incurred in the past just as much as a banking sector problem per se. ${ }^{5}$ This allows us to put some of the large restructuring costs in perspective. The scale of a 10\% of GDP restructuring cost may be more readily understood if it represents the accumulation of a decade of hidden quasi-fiscal deficits. ${ }^{6}$

The degree of democratic legitimacy of the regime may colour one's interpretation of directed lending programmes. In the Philippines, much of the loan losses of the two large banks bailed out in the late 1980s were said to have enriched President Marcos and his associates, directly or indirectly.

\section{Autonomy of regional governments}

An additional twist is provided in the case of countries with a federal structure when state governments use banks (which may be owned by them) as sources of funding for their own borrowing needs, or those of suppliers. The incentive for each state or provincial government to exploit the

5 This is consistent with, for example, the readiness of the Government of Cote d'Ivoire to restore the viability of the local commercial banks by assuming responsibility for very substantial public enterprise loans that had long been in arrears.

6 But it is important to recognise that use of the banks as an arm of government not only crowds out the remainder of the economy from access to loanable funds, but has other corrosive indirect effects such as degrading the quality of bank performance in terms of credit appraisal and lowering the accepted standards of contract enforcement in the economy generally. 
potential for imposing external costs on the others has been well exemplified by recent history. Loan delinquencies by state governments, and their (unpaid) suppliers, have been at the root of the large insolvencies of state-owned banks in Brazil (1994-95) and Nigeria (1993). In both cases, the central bank has stepped in to provide liquidity support: in effect, the state governments have thus been able to leverage loans indirectly from the (federal) central bank. Exactly the same pattern has been in evidence in the Franc Zone, where the regional central banks have had to bear substantial losses on the debts of banks which failed partly as a result of losses on loans to state enterprises, or government suppliers in the different member states.

There are parallels with the behaviour of provincial branches of The People's Bank of China in extending credit to provincial enterprises in excess of the centrally determined policy; this was an important feature of credit policy evolution in China at least until 1989.

\section{Transition economies}

The banking system that emerged from the planned economy and which formed the largest initial element of transition economies' financial system represents, of course, the extreme example of government-permeated banking. Under the planned regime, bankers had made essentially no assessment of creditworthiness: their job was to implement and monitor the credit plan devised elsewhere. ${ }^{7}$

\section{Other government mechanisms weakening banks}

Poor loan loss experience is not the only way in which government pressure on banking systems reveals itself. Banks have often been pressed into borrowing from abroad in foreign exchange and assuming the exchange risk. This action eases pressure on the official reserves, and may postpone pressure for devaluation. However, if the devaluation occurs, it may well result in insolvency for the banks. This was the experience with several large development banks in Ghana, whose official exchange rate in the early 1980s, when the banks undertook the borrowings, was well out of line with market realities.

In Latin America, a tradition of high reserve requirements, combined with the possibility of rediscounts from the central bank, interacted with a volatile interest rate and inflation development in the 1980s to place the viability of many banks at the mercy of central bank policy. Argentina represents the most extreme example, with a system of monetary compensation payments being

7 The evolution of banking systems in transition has followed a variety of paths (Borish et al. (1995) and Claessens (1996)), showing that this regime change does not predetermine future developments. Among the dimensions in which transition systems have diverged are the degree to which new privately owned banks have emerged to deal with new clients (and whether they are adequately capitalised and managed), dependence on central bank refinancing, restructuring and recapitalisation of the post-monobank state-owned institutions (and whether this implies soft budget constraints), privatisation of these and the retention of substantial sectorally specialised institutions. On the basis of statistical analysis of expert ratings, Claessens suggests that radical change leads more quickly to a healthy banking system than gradualism. 
operated by the central bank to eliminate the adverse effect on bank profitability of controlled lending rates and forced investment in unremunerative official paper. By the late 1980s, the financial autonomy of the banks was completely eroded, as they responded to the deposit withdrawals associated with surges of speculation against the currency by raising deposit rates to extremely high levels (over 100\% per month on occasion), and then received offsetting subsidies from the central bank. (This system terminated in January 1989 with the confiscatory funding of most of the deposit liabilities under the so-called Bonex plan.)

This experience has echoes in Chile's period of recovery from the crash of 1981-82 during which the authorities adopted a wide range of subsidies with the objective of ensuring the banks' viability. Less dramatically, one may notice the impact of government credit or borrowing policies on the profits of banks in Ghana, ${ }^{8}$ Greece, the Philippines ${ }^{9}$ and Turkey ${ }^{10}$. Because they were on a smaller scale, these last-mentioned cases fall short of resulting in a government-dominated banking system, but they do illustrate the social costs that can be involved even when banks do not explicitly fail.

At the limit of this type of regime, where the profitability of banks is assured only by massive flow subsidies, the solvency or otherwise of the banking system has become entirely a matter of fiscal discretion. Of course it is often the prior repression of the system through onerous taxes or requirements that leaves it so vulnerable. Heavy and variable taxation, explicit or implicit, alters the basis on which banking is conducted and leads to a loss of autonomy and banking prudence.

\subsection{Evolution of the crisis: the role of regime changes}

Sifting through the evolution of many crises after the event we generally find that the seeds were sown long before the denouement. But despite the creeping nature of the problem, it is often possible to trace the crisis back to a regime shift which altered the nature, scale, frequency and correlation pattern of shocks to the economic and financial system. Often external to the banks, it was this regime shift that heightened the vulnerability of the system, whether by altering the incentives facing banks, increasing the riskiness of traditional behaviour, or introducing new and inexperienced players. Typically, although this shift in the stochastic environment will have been perceptible - and may have resulted from a policy change - the degree to which it increased uncertainty was not fully appreciated by market participants or by the authorities. After years of stability, they underestimated the potential for problems to arise, and continued to operate on the basis of rules and procedures

8 By maintaining tight credit ceilings during a period of substantial capital inflows in the late 1980s, Ghana effectively passed market power to the banks, allowing them to increase the spread between deposit and lending rates.

9 Stabilisation policy in the Philippines after the mid-1980s crisis involved the aggressive sale of central bank bills at very high yields. Although it did induce some disintermediation, this had a favourable impact on the profitability of the banking system.

10 High interest rates in Turkey have strongly supported the viability of weak banks in the last couple of years. 
which were adequate to the previous environment, but might not cope with the new circumstances. The result was increased vulnerability of the financial system to failure.

Although rendered vulnerable by the regime shift, the system is not yet doomed to crisis. Depending on its inherent robustness and its ability to learn, the system (including the regulatory structure) may be able to adapt to the new circumstances before a major crisis strikes. Thus there is an interval of heightened vulnerability in which corrective action is possible. This is the window of time which makes anticipatory action worth trying. If it is not taken, eventually a large disturbance triggers the crisis.

By their very nature, future regime changes will not necessarily follow a predictable pattern. It is nevertheless worth providing a checklist of the main types we have noticed.

\subsubsection{Financial repression}

An increase in the degree to which the government is using the financial system to squeeze resources to support the budget directly or indirectly can expose banks to an erosion of their capital base. ${ }^{11}$ On the other hand, when the authorities become aware of a risk to the viability of the system, they often provide opportunities for the banks to earn profits through high-margin business often at the expense of the consumer. This may be achieved by limiting competition, including the imposition of credit ceilings.

\subsubsection{Financial liberalisation}

Whereas it is the quasi-fiscal impositions of financial repression that pose risks, a repressed financial system is at least protected from some of the risks posed by financial liberalisation, especially the removal of interest rate controls and the liberalisation of entry. Particularly where macro conditions are not stable, the overall level of interest rates can become very volatile following liberalisation, and may remain very high in real terms for an extended period. The most striking examples are in Chile in the late 1970s, and again in some of the transition economies. The Chilean experience included real lending rates that averaged $77 \%$ per annum over $1975-82$, despite the absence of major implicit taxes, and without high inflation. Faced with such conditions, it is not surprising that Chilean banks borrowed heavily in foreign currency and onlent to their customers in the same (Diaz-Alejandro (1985)). By passing on the exchange risk, the Chilean banks may have

11 The government also benefits from the implicit inflation tax on currency, but that need not per se represent a burden to the banks or financial intermediaries; on the contrary, these have sometimes benefited from the existence of a high-inflation environment. The case of the Brazilian banks, whose skill in providing treasury services in an environment of high and variable inflation contributed to high profits and an enormous expansion in their business, is well-known. 
thought that the foreign aspect of this business presented no risks, but events proved that they were merely substituting credit risk for exchange risk.

The increased competition and the resulting struggle for market share that follows liberalisation of entry conditions can result in narrower margins and unsound lending practices. This has been documented for a wide range of countries from the United Kingdom in the early 1970s to Indonesia and Russia today. The consequences can take a number of different routes and may show up in more than one of our syndromes. (substantial volume increases, new and unfamiliar types of clientele). Liberalisation of interest rates and/or the foreign exchange market is usually followed by increased exposure to market risk.

\subsubsection{Macroeconomic instability}

A change in exchange rate policy, a deterioration in the public finances or any of a number of other sources of monetary instability present risks that may not be fully appreciated by market participants. This is most evident in the case of an innovation to exchange rate policy which can dramatically alter operating conditions for banks. The tablita policy of the Southern Cone countries in the period 1979-82 is the most famous case, in that, though it induced gradual currency overvaluation, banks behaved as if the projected exchange rate path was a viable one, and undertook unwise foreign borrowing. ${ }^{12}$ A sharp upturn in economic conditions can set the scene for subsequent banking disaster if bankers become intoxicated with the atmosphere of euphoria and a widespread perception that extremely favourable conditions are set to continue.

\subsubsection{Structural economic transformation}

It is hardly necessary to stress the difficulties presented to existing and new banks in countries undergoing structural economic transformation. This is regime change par excellence. Not only do existing banks have to deal with client enterprises which (whether or not they were viable at pre-reform prices) are not viable with the newly prevailing structure of demand and prices at least with their existing scale of operations and product line. In addition the banks may become responsible for their own financial viability in a way that was hitherto unknown. Turbulent interest rate and exchange rate movements and the breakdown of normal trade and payments arrangements accompanied the early years of transition, and are still present in many of the countries concerned. Where the old banks have chosen to exercise forbearance with regard to the unserviceable debts of their old clients (or where they have been pressed to do so - the confused lines of authority often make

12 More recently, the dramatic stabilisation of the Brazilian currency from mid-1994 has effectively removed a large source of revenue for Brazilian banks (see previous footnote), implying that they must shrink. This not only poses new difficulties, but makes it harder to conceal underlying problems. The collapse in 1995-96 of two large private banks, and deepening difficulties at several publicly owned ones, confirm the diagnosis. 
it difficult for the managers of these banks to choose between a commercial and a political approach) they have tended to remain tied to these customers, allowing new banks to capture a growing share of the business of the more profitable and growing enterprises. But even these new banks are working in a most uncertain and physically insecure environment, where the normal rule of law cannot be taken for granted. In such conditions, even the most conservative banker runs the risk of failure, and it is to these conditions that the unscrupulous are most readily attracted.

\subsubsection{Political developments}

Even less dramatic changes in the political environment may present a variety of unforeseen problems. For example, emergence from a repressed political regime may leave financial contracts open to hitherto unknown types of opportunistic behaviour or fraud by private sector counterparties. The total collapse of the Guinean banking system in 1985 is sometimes attributed to the removal of inhibitions in the more relaxed conditions following the Sekou Toure regime. ${ }^{13}$ Another type of risk is that the government of a fragile democracy may turn to the banks for resources in a hitherto unfamiliar manner and may be accommodated in a way that would not happen with a more experienced banking system. The most common banking sequel to a change of government is not, however, a change in the environment, but the emergence of abuse and fraud which had been concealed through the political protection of the previous regime. The Philippines in 1985 and Venezuela in 1994 are clear-cut examples.

\subsubsection{Privatisation}

Often hailed as the panacea for banking weaknesses of one sort or another, privatisation has all too often been the regime change which incubated more serious problems. This has been the case both in transition economies and in developing countries that had operated with state-owned banks. The problem has generally lain in the lack of suitability or experience of the new owners, the inadequate capitalisation of the privatised banks or both.

\subsubsection{Technological innovation and globalisation in finance}

Technological change in finance has been an underlying factor both in increasing competitive pressures by undermining the dominant position of local banks and in opening up new and untested areas of operation. The potential risks associated with financial derivatives have been extensively discussed in this latter regard, though the isolated cases mentioned earlier are not enough to make derivatives an important cause of systemic bank failure. Potential exposure of banks to local

13 Under that regime, banks had so little autonomy that they failed to learn the most elementary behavioural norms of institutional survival, leaving themselves wide open to fraud. 
stock market risks could become an issue for the future, if domestic banks seek innovative financial instruments to give them a share of the substantial long-term gains likely to be on offer in these markets.

The increased volume of inward portfolio investment in many developing countries is perhaps the most significant recent regime change affecting a wide group of countries and potentially setting the scene for future crisis.

\section{Collecting data for early warning}

\subsection{Ruling out particular syndromes}

Assuming that supervisory authorities are sensitised to the risks presented by regime changes, they still need to detect the early signs of an emerging crisis. Individual bank problems can often be foreseen by skilful use of standard techniques of peer-group analysis. But what if the system as a whole is heading for trouble? Here there does seem to be something of both a methodological and a data vacuum. The metaphor of the three syndromes provides a useful organising principle in sharpening the inferential value of such data as can be collected.

If you don't know which syndrome you are looking for, the data can mislead badly. But it should be possible to rule out one or two of the syndromes in any particular country from a fairly informal examination of current conditions and of "market gossip". Of course the latter is not reliable, but (especially as it is prone to exaggeration) may be used in a negative way as a pointer to the absence of problems. For example, political lending pressures are always rumoured when present, and sometimes when not. If not rumoured, they are not important. The same is true of recklessness and fraud: these are more commonly reported (though not verifiably) than actually present. ${ }^{14}$ Fragility of banking is not so easy for the outsider to detect: if it is widespread, it probably also infects the usual informal sources of banking opinion and may therefore not be reported.

\subsection{The structural indicators}

Having decided which syndrome one is looking for, the next stage is to track the evolution of indicators that might warn of its presence. This section briefly lists some indicators that could be useful. The list (the Annex provides a fuller account) is organised by syndrome and includes both indicators that are available and those which could be made available with limited effort.

14 But not everyone reads the signals, as in the cautionary tale of Banco Nacional in Brazil, whose shares were recommended as a hold by New York investment advisers Salomon Brothers very shortly before the collapse. 


\subsubsection{Indicators for macroeconomic epidemics}

The endogenous form of this type of crisis has fairly clear characteristics. Unusual asset price movements, rapid growth of lending especially for property transactions and for financing of stock market positions, capital inflows: these are some of the tell-tale signals of a credit-financed asset price boom which may prove to be unsustainable.

\section{Aggregate balance-sheet and operating account data suggesting unsound banking}

These apply also to syndrome 2.2.2 below. Indicators which are used at the level of the individual bank as warning signs can also be used at the aggregate level to flag systems at risk. For example, growth in aggregate lending; the loan-to-deposit ratio; and reliance on foreign borrowing. Higher values of each suggest a banking system that may be overreaching its resources in more ways than merely financial. Also, from the operating accounts, the gross interest margin (indicative of profitability) and the share of non-interest income in total income (indicative of weakness in the core business).

\section{Specific indicators for macro-cycles}

Rapid growth of aggregate bank lending to the commercial property sector should be used as an indicator, as should the gap between current and trend values of the price of real estate property and of equities. Substantial aggregate inflows of portfolio capital would also be a warning sign.

Although the warning signs are clear, their interpretation will be disputed. Nobody can be confident of knowing that a boom is unsustainable, or when the crash will occur. An equilibrium of cognitive dissonance can be envisaged: thus, given the resistance and scepticism with which proposals for corrective action will be met, those concerned with preventing crises will err on the side of predicting more crises than actually occur.

Finally, an additional source of information, not often readily available, but pointing to a direction in which data collection could be improved over time, is the increase in enterprise indebtedness as measured by the growth in leverage in a sample of enterprise accounts (see Tybout (1986)).

\subsubsection{Indicators of poor management and other microeconomic deficiencies}

In examining the system for weakness under this heading, we want to know if the banks are financially sound, and whether they are being managed in a prudent manner by trustworthy persons. In addition to the publicly available balance-sheet and operating account information already discussed above, possible sources of information include: 


\section{Market-based indicators}

Because fraud and reckless behaviour must be concealed if it is to be successful, it is hard to find conclusive evidence before the damage is done. The business of bankers being to assess creditworthiness, they are among the best-placed to know or suspect which of the system's institutions have problems. Their suspicions will partly be revealed by prices in, and the functioning of, the short-term money markets. ${ }^{15}$ Market rumours and loss of confidence in banks which have been involved in fraudulent or reckless behaviour often predate any clear evidence of their difficulties. Such banks may be excluded from borrowing on the interbank market, and may be paying higher interest rates on deposits for some time before collapse. Therefore, we suggest three measures here. First, if a large proportion of the banks have no de facto access to the interbank market, or have access only at high rates, then this is a clear warning sign. Second, information about the range between the rates being offered by different banks on large time deposits is also informative (and would, for example, have clearly flagged the Banco Latino in Venezuela months before it failed). This information should be collected by the central bank on a much more systematic basis than is common at present. The third market measure, suggested by historical studies as well as by contemporary observation, is the (tax-adjusted) gap between Treasury bill and large bank deposit (or CD) rates.

\section{Regulatory information}

Of the information available to regulators, the most useful kind is loan loss experience and the ratio of capital to risk-weighted assets. Even though banker optimism, or the desire to conceal the worst from regulators, means that the really large deteriorations in these indicators usually happen after the crisis is known to all, nevertheless small changes may be leading indicators of solvency problems.

The quality of regulation is also at issue. With nearly all countries now sensitised to the need for a good system and general agreement on the main design elements of such a system, the most common areas of deficiency are: delays in legislation, leaving regulators without the powers they require; weak enforcement; and technical inadequacies either in the regulations or in the quality of supervision. Short of a full assessment of the adequacy of the regulatory and supervisory system (a matter to which we return below), the answers to three simple questions should reveal much about the likely effectiveness of the regulatory system:

- First, what is the status of planned legislation in bank supervision and what is the nature of any delays encountered?

15 In addition, commercial rating agencies are beginning to rate the main banks in a few developing countries. 
- Second, who authorises waivers or exemptions to regulatory norms, and how frequent and widespread are such exemptions; are any banks in violation of regulatory norms without having received exemption?

- Third, has each significant bank been inspected on-site within the past two years?

\subsubsection{Indicators of a government-permeated banking system}

Financial crises which are chiefly associated with government interference in the banking system are typically gradual affairs. Structural features which hint at the potential for problems of this type include:

- Government ownership of a large segment of the banking system is often a sign of problems to come, although as indicated, even the lending of private banks can be controlled by government.

- The proportion of lending that is at the free discretion of banks, that is, not subject to compulsory deposits or sectoral allocations, is a key parameter. The compulsory component may be made up of any or all of compulsory reserves held at the central bank or compulsory investment in government securities or lending to specified borrowers or to a fund whose disposition is not at the discretion of the bank. Sectoral allocations usually come in the form of minimum proportions of the asset portfolio to be held in loans to certain broad categories such as agriculture, particular geographical regions or ethnic groups.

- Borrowing from the central bank often entails some degree of official control over the banks' use of the credit; this should be another indicator.

- The scale of implicit or explicit financial intermediation taxation is also an indicator of government reliance on the banking system; likewise a high level of government subsidy of the banking system may indicate that the system has fallen into a state of dependency, possibly as a result of previous government pressures. Measuring these requires some work, though methodologies have been developed and applied to many cases.

Finally, there is a potential application here of some indicators of political risk. The political structures and traditions of a society will be an important additional influence on the vulnerability of the banking system to predation from political powers. Relevant dimensions would be the degree of concentration of political power in elite groups, the freedom of the press, and the autonomy of regional governments vis-à-vis the centre. In practice, political indicators may be constructed either through direct measurement of such political structures, or by drawing on one or other of the multipurpose political risk judgemental indicators marketed by commercial firms. 


\section{Setting financial policy to reduce vulnerability}

The three failure syndromes elaborated above also offer a convenient framework in this section for classifying issues of prevention. Macroeconomic stabilisation policy has its part to play, and must not be derailed by short-termism in financial sector policy. Although some scholars still argue in favour of laissez-faire in banking, on the grounds that regulation might create more distortions than it removes, a clear majority view favours close microeconomic supervision of bank practice and enforcement of capital adequacy rules. There is a consensus on the major features which such prudential regulation should have in developing countries. But regulatory enforcement may be inhibited by political pressures: new institutional structures may be needed to strengthen the regulators' hand. Increased internationalisation can help on a wide front.

\subsection{Macroeconomic and banking system stability}

There is no doubt that a return to greater stability of real and especially nominal macroeconomic variables would help reduce the riskiness of the environment facing banks and bank regulators. However, protecting the solvency of banks and other financial sector participants is not the primary reason for seeking macroeconomic stability. Therefore, to rely on advocacy of macroeconomic stabilisation policy is really an evasion of the specific policy issues that arise in relation to macroeconomic aspects of financial sector failure.

Indeed, the real problem is often that banking sector weakness can place obstacles in the way of needed deflationary policy. When the capital of many banks has been allowed to erode, and when the banks have acquired an investment portfolio that exposes them to interest rate risk, a foreign exchange position that exposes them to exchange rate risk, or a loan portfolio that makes them highly vulnerable to an economic slowdown (if the ability of many borrowers to service their loans is dependent on continued buoyancy in property prices and extremely strong demand conditions generally), then macroeconomic stabilisation is difficult indeed. Even a small corrective policy step, such as an increase in interest rates, or a tightening of fiscal policy, may tilt several banks into insolvency and failure, with wider and hard-to-manage consequences. It can become unclear whether expansionary or contractionary policy will affect banks more adversely. To avoid a fall in the foreign exchange value of the currency (which could bankrupt those exposed to foreign exchange risk) an increase in interest rates might be needed (but that would cause difficulties for others). In short, the problems of a weak banking system can paralyse macroeconomic stabilisation policy.

If a weak banking system impedes macroeconomic stability (and of course it should not have been allowed to reach that stage), then correction of this weakness, probably requiring farreaching measures, will be required sooner or later. Deferral of needed macro-stabilisation will not by itself ease the position of the banks. Therefore, although it would be foolhardy to imply that a general prescription is valid for all cases, the presumption must be that measures necessary for macro-stability 
should not be deferred, and at the same time the weak banks should be promptly intervened, with whatever liquidity support is needed for the system to offset depositor panics. In this sense, bank rescue policy should normally be subordinate to stabilisation of the macroeconomy.

This is all more easily said than done. In particular, it requires a nice balance between tightening of the cost of credit while providing adequate liquidity to meet the increase in liquidity preference that may follow the revelation of bank weakness. Nevertheless, it offers what seems an inescapable logical priority: banking system weakness should not be allowed to derail macroeconomic stabilisation. After all, in the longer term, the more stable the macroeconomic performance, the easier it will be to avoid future emergence of widespread banking weakness.

\subsection{Building a robust regulatory system: consensus on most technicalities}

\subsubsection{The consensus}

The emergence of banking problems in developing countries has led to reappraisal of financial policy design in these countries. This reappraisal was able to draw on recent improvements in the design of banking regulations for industrial countries spearheaded by the work of the Basle Committee (see Padoa-Schioppa (1996)). The result has been a virtual consensus on many of the main regulatory structures that need to be put in place in order for the financial system to display robustness in the face of shocks. ${ }^{16}$

The consensus view on financial policy begins with the idea that the system should be free of the onerous and highly distorting taxes and quasi-taxes (especially interest rates controlled at unrealistic levels) that were a common feature of most banking systems in the past. Not only does the removal of these impositions free the bank's management to devote its attention to creditworthiness as the major criterion for lending decisions, but it ensures that the bank's decision-makers have an incentive to make sound loans.

The achievement of good results in prudential regulation (as seen by the consensus view) requires adequate flows of information, qualitative as well as quantitative; adequate standards of solvency with reference to the risks being assumed; and adequate powers and independence for the supervisory agency to take graduated action to prevent unsound behaviour.

Of course one must also recognise the inevitable limitations of regulation. For example, solvency standards are only as good as the measure of capital. ${ }^{17}$ Supervision is relatively ineffective against fraud, especially when the burden of proof is on the regulator. The increasing complexity of

\footnotetext{
16 Most of the technicalities that remain under discussion in the industrial country context are of less urgency in developing countries given the existing and prospective structure of their banking and financial systems.

17 The recent Mexican crisis was marked by an almost perfect reported capital adequacy record for the banks right up to the eve of the crisis.
} 
market-related instruments held by banks and the speed with which their value can change sharply limits the value of occasional inspection and reporting. It will be some time before many of the systems that are now being put in place in industrial countries to try to keep up with this evolution can be transferred to developing countries. Regulators may be under pressures that induce them to forbear to intervene in the activities of unsound banks. ${ }^{18}$

But above all, supervision will also be of little use if not backed up by a political will to move against what may be powerful financial interests for the sake of protecting the taxpayer from the costs of failure (a point to which we return below).

\subsubsection{Design of regulation: some adaptations needed for developing countries}

For developing countries it is not, therefore, so much a matter of designing the regulations, as of ensuring that they are in place and effective. There are, however, a couple of important respects in which the industrial country regulatory structures are not adequate for the needs of developing countries. One relates to the overall percentage capitalisation requirement, and the other to the treatment of lending to government.

The capital requirements against risk assets chosen by the industrial country regulators were calibrated for industrial countries whose economies are generally larger and less vulnerable to exogenous shocks; furthermore, these ratios were adopted under pressure of international regulatory competition. They are not tough enough for most developing countries. Imposing higher requirements will appear onerous and possibly an impediment to financing development, but the conclusion seems inescapable if we wish to give the bank regulators in developing countries a realistic chance of intervening in a failing bank before all the capital is eroded. The establishment of appropriate capitalisation levels for country circumstances is a matter which needs to be considered on a country-by-country basis. There is clearly a risk that increased capital requirements could lead to disintermediation and the booking of loans in offshore subsidiaries, so issues of international coordination may arise.

The assignment of a zero risk weighting to own-government debt is also questionable for developing countries, considering the frequent instances of direct and indirect arrears by developing country governments. The principle is often stated whereby a national government can always "print its own money" to repay the banks, and so need never be in default, but this may not be the case where a currency board system is in effect, where the country participates in a currency union, or where the government has otherwise forsworn the use of monetary financing. Even when governments have faced up to their loan delinquencies, they have sometimes secured preferential consolidation which has been tantamount to a partial default, so far as the banks' profit and loss account is

18 See Kane (1995) and Boot and Thakor (1993), who express this as a problem of imperfect agency. It can happen because of a fear of revealing early deficiencies in regulation and in the hope that the banks may recover anyway. 
concerned. All in all, there is sufficient reason to reject the idea that lending to own government is riskless for banks.

\subsubsection{Speed limits}

Although the consensus approach recognises that regulatory avoidance makes it no longer realistic or desirable to try to influence the structure of banking system portfolios on a longterm basis, some suggestions in the direction of re-regulation have been mooted. The most promising of these, so far as bank soundness is concerned, is the proposal for some kind of "speed limits" on bank asset growth (see Caprio et al. (1994) and Vittas (1992)). This idea draws on the common observation that rapid growth in loan portfolios is often present in individual bank failures and, as we have seen, in some types of systemic crisis. Although regulators can always ex post target a bank with rapid loan growth for special examination, the damage may already have been done. Why not simply limit the rate of loan portfolio growth ex ante? Such an arbitrary friction may induce avoidance through the use of unregulated near-banks or offshore entities. However, if the speed limits are pitched sufficiently high, they will bind too rarely to trigger avoidance, considering the fixed costs that may be required to set up avoidance procedures.

Temporary speed limits are worth considering in a market which has many new and hence inexperienced entrants, and inadequate supervisory resources, or may be an effective way of choking off an incipient boom. But they are unlikely to feature as part of the optimal long-term toolkit. Besides, excessive credit growth only predicts some crises: this measure has the feel about it of being a solution to "last year's problem".

But it would seem unwise to go beyond the idea of speed limits to entertain some of the more complex prudential rules which have been proposed with the intention of making the regulatory system more responsive to exogenous changes. For example, there has been the suggestion that capital ratios should be linked to macroeconomic conditions, thereby providing a more refined structure of incentives for the bank, and avoiding, for example, the possibility that the regulations could lead to credit policy being destabilising (as when loan provisions increase in a recession, contributing to a credit crunch). While such complex incentive packages can be designed in theory, it is less clear that the theoretical constructs can be reliably transformed into soundly based operational rules. For developing countries at least, implementation of simple and sensible rules seems more urgent.

\subsection{Political obstacles to effective regulation}

Weak enforcement due to political interference is the Achilles' heel of any regulatory system. Early response to emergent banking problems has been repeatedly inhibited by the political protection against closure which unsound banks and imprudent or self-serving bankers appear to have enjoyed. The resulting delays have deepened the ensuing crisis. 
Designing institutional and political arrangements that will make such protection less likely is a difficult challenge. For one thing, bank intervention is often not seen as a desirable political good. Two of the possibilities that have been suggested to enhance the political desirability of sound banking and thereby strengthen the hand of the regulator, namely limiting deposit protection and greater disclosure, are worth considering. ${ }^{19}$ When depositors are fully indemnified from banking failure, the major potential beneficiaries of sound banking are the taxpayers, who represent a normally diffuse lobby. Not only will unprotected but better informed depositors be more cautious about where they place their funds, but they will also see the regulators as their agents and clamour for early regulatory intervention.

\subsubsection{Deposit insurance and the narrow bank}

Can the taxpayer's exposure to bank failures be limited by defining the parameters of explicit deposit protection in such a way as to make full rescue politically unrealistic? Is there ever an advantage to introducing explicit deposit protection during a period of vulnerability or of imminent crisis? Can the concept of a "narrow bank" be effectively employed here, or will such a scheme so limit the effectiveness of bank intermediation as to be more costly than it is worth? These questions have been widely discussed and remain open in the literature.

Narrow banking covers a variety of proposals all of which amount to defining a class of deposits which is to be backed by securities of such undoubted liquidity and safety that the bank's ability to meet depositors' withdrawals cannot be called into question. Most (but not all) countries have sufficient such assets to back the existing stock of demand deposits, suggesting that the idea is not infeasible. Furthermore, using an adequately supervised holding company structure, a banking group could continue to benefit from the scope and information economies associated with deposit, money transmission and lending activities while still segregating the special deposits from the risks associated with lending and other banking activities.

The questions of narrow banking and deposit insurance are tightly linked as they relate crucially to the credibility of government and its ability to commit itself to avoiding bailouts. Both limited deposit insurance and narrow banking lose their rationale if they fail to alter depositors' perception as to the likelihood of intervention in the event of need. Where such credibility exists they may be very useful, otherwise not. Greater public awareness of the costs of the current round of crashes may enhance the political acceptability of limiting future coverage of deposits.

Many observers have criticised the introduction of blanket deposit coverage during a widespread crisis or incipient bank run as having the worst kind of incentive effects, and of

19 As are increased internationalisation (discussed in subsection 4 below) and privatisation. Whereas the management of a government-owned bank has built-in access to authorities who can forestall or overrule regulators, this is not necessarily the case with a privatised bank (though bank owners are also likely to be well-connected politically). 
undermining all attempts to establish credibility in times of calm. But it still happens. Undoubtedly, such action can be effective in stemming a depositor run (as in Turkey in 1994), though not if the target of the run is the currency as much as the banks. Certainly a selective run in favour of strong banks should not be met with a blanket deposit insurance, as lender of last resort facilities can, at much lower cost, be deployed to protect banks which the authorities believe to be sound.

Despite the lack of a consensus in the profession on the best way forward here, there is no doubt that a lack of definition of the scope of deposit insurance is a serious structural flaw in the structure of incentives in the system which allows and almost encourages abuses.

\subsubsection{Disclosure}

Is it really a good idea to disclose full details of a bank's balance sheet and income position? Many authors insist that this must be so, given the ability of market participants to process information and the distortions that arise when information is asymmetrically distributed. Ensuring prompt disclosure of all relevant information is also a central concern of the regulators of securities markets. It is noteworthy, however, that not all bank regulators agree. Their concerns appear to be with the risk of an irrational depositor response aggravating the position of a bank which is suffering from temporary and recoverable weakness. It is sometimes argued that, by forcing early liquidation of such a bank's portfolio, such depositor withdrawals may impose avoidable social costs.

From an analytical point of view, the issue of disclosure is closely related to that of forbearance. If the purpose of non-disclosure is to facilitate the continued operation of a bank which the market would close if it had the relevant information, then it also implies that the authorities (who have the information) are forbearing to take closure action themselves. Although some theoreticians have dreamed up circumstances under which forbearance would be desirable it is widely accepted that forbearance and non-disclosure weaken incentive structures and ease the work of political lobbyists who would seek to restrain regulatory action.

Disclosure multiplies the number of watchful eyes and should induce a more cautious management stance. Inevitably, disclosure may shorten the time interval between the emergence of liquidity and solvency problems at a bank, as it will improve the information on which depositors and other lenders to the bank will base their decisions. However, early regulatory intervention in the affairs of an insolvent bank is desirable anyway. Recalling the earlier discussion of contagion, specifically its relative infrequence and the tendency for runs to be focused on banks that are truly insolvent, we conclude that the advantages of extensive disclosure outweigh the risk of some destabilisation. 


\subsection{Positive aspects of international financial integration}

\subsubsection{Can internationalisation provide insulation?}

Though there is much concern that increased globalisation of financial markets can increase the volatility of capital flows, globalisation can also provide an opportunity to diversify some of the risks faced by a small and closed financial system. This should be exploited by policy to strengthen the resilience of financial systems in small economies. Innovative risk-sharing financial instruments can help, but achieving the full potential may require stronger ownership links between financial institutions at home and abroad.

This line of reasoning relies on the observation that, while some elements of the rapid technological development in finance may have contributed to risk, in general the increased diversity and complexity of the network of financial institutions has increased the resilience of sophisticated financial systems to isolated failure (Honohan and Vittas (1996)). Not every country can expect to build a comparable complexity by itself, but by becoming more integrated into the international financial network it can obtain the benefits of increased resilience as well as risk diversification.

After all, most of what are macroeconomic shocks for a small country are only regional or sectoral shocks for the global economy. The risk of such shocks can in principle be diversified. One theoretical option is diversification through market instruments. Banks might find ways of selling or swapping part of their loan portfolio to banks in other countries. Or marketed derivative instruments linked to objective indicators correlated with national economic conditions could provide the vehicle. Exploration of the institutional arrangements that might be needed to support such innovation is beyond the scope of the present paper. The alternative, and more practical, option is greater involvement of foreign-owned banks in domestic banking. For example, heavy loan losses at the local branch of a multinational bank will not entail failure of the bank.

Likewise when we consider the microeconomic syndrome and the government pressure types of crisis the advantages of greater participation of foreign banks can be seen. They can bring with them experience and systems. Concentration of lending is less likely to be condoned, especially to associates of the local management. Local euphoria is also less likely to be given free rein in lending decisions. Internal bank controls to inhibit such behaviour are likely to be much more effective than external regulation and supervision. Government pressure can be more readily resisted.

An important obstacle to this approach is the common perception that foreign ownership of banks compromises sovereignty. It has to be acknowledged that concerns along this dimension are not wholly groundless.

And even where they are welcomed, foreign-owned banks may not be rushing to enter. Experience to date of foreign-owned banks in developing countries varies but, with some exceptions, such banks have tended to confine themselves substantially to servicing the activities of foreign 
enterprises (especially enterprises from the bank's home country) and the trade finance requirements of the largest domestic enterprises. Partly as a result of this, but also because of better management procedures and less pressure from governments, the incidence of failure of foreign-owned banks has often been much lower than for local banks - even though their lack of local information can make their lending decisions hazardous. Nevertheless, the expansion of US and other industrial country banks into onshore banking in many developing countries in Africa and Latin America during the 1960s and 1970s often had disappointing results for those banks, and the relatively modest response to recent possibilities opened up by the changes in Eastern Europe and the Soviet Union, and in the single European market, suggests that industrial country banks will remain highly selective in their entry decisions.

Obviously there are no simple and immediate solutions here. But the traditional view which stressed the advantages of delayed liberalisation of the capital account of the balance of payments in protecting the domestic financial system from destabilising capital flows must now make some room for this type of argument based on the insulating properties of the global financial network.

\subsubsection{An international seal of approval}

At several points we have argued that the existence of some form of international seal of approval can help promote the incentive structure that is needed. This can partly be achieved through an international expansion of the activities of private rating agencies and the research teams of international investment banks. These have begun to expand their activities into the developing and transitional world, and their reports on selected banks should begin to feed back usefully on regulator and government performance. However, they only find it worth their while to cover the larger banks in the larger countries.

Therefore the question arises as to whether there should be some public international initiative on regulatory and supervisory standards going beyond the current process of progressive adoption by other countries of the Basle norms. ${ }^{20}$

One specific idea is that an international rating classification for financial systems would be available to each national authority. The government could apply to have its banking system and regime of bank regulation and supervision rated. The ratings would be published. The rating agency would rate different segments of the banking system separately, but there would be no intention to include a bank-by-bank rating. The rating report would also evaluate policy, distinguishing between the quality of regulation, supervision and enforcement. In approaching the task, the agency would

20 This might seem to be a departure from the principle of home-country regulation adopted between industrial countries, but bear in mind that (outside the European Union) this principle can already be overridden if the host country is not satisfied with the quality of the home country's regulatory procedures. 
naturally be looking at indicators such as those discussed in Section III above, but would need to go into greater detail and also make qualitative evaluations on the basis of interviews.

The very existence of such a rating system would alter the incentives for those governments which are disposed to interfere excessively in their banking systems. Failure to seek a rating, or securing a low rating, would impact negatively on their economic and political performance. Those governments which do not want to abuse the financial banking system but which, perhaps because of a history of abuse, lack credibility in this regard, would benefit too.

The international community would also gain collectively, justifying what would inevitably involve costs of design and implementation, whether the rating system was to be operated by a single public body or (more likely) competitively by private or public agencies.

Whatever international body or bodies are involved, a key element is that the proposed seal of approval, or graded rating of regulatory regimes, would be sought by the authorities, and the results made public in order to ensure that it encourages the appropriate incentives for the regulators and the government.

\section{Concluding remarks}

Closer international cooperation in banking regulation offers clear advantages to all countries in the attempt to forestall future systemic problems of each of the types we have discussed. Macroeconomic instability, though it has an important domestic component, is often linked to external shocks. Microeconomic deficiencies are often tied in with foreign exchange and offshore transactions requiring close and trusting contacts between regulators in different countries. Relatively strong externalities mean that each country gains from the quality of regulation and of macroeconomic stabilisation policy in its financial and trading partners.

But our review also highlights the need to distinguish between technicalities and errors on the one hand, and abuse on the other. Policy errors have certainly played a part, and they can be addressed through better legislation and regulatory design, improved training of supervisors and adequate resources of the supervisory authority, and greater attention to the importance of avoiding macroeconomic overheating. But it is in the area of reducing what must, in conventional terms, be regarded as abuses that the most important reforms must be sought.

From the economist's perspective, the most interesting way of curbing abuse is by altering the incentive structure faced by the various participants: bankers, depositors, regulators and the government itself. When it comes to the incentive structure for government, we move into the grey area between fiscal policy on the one hand and issues of governance and even of political corruption on the other. These issues must be squarely faced if there is to be decisive progress in reducing the fragility of banking systems. 
To some extent, lessons will have been learnt from recent experience. The stagnation or failure of banking systems which have been pressed too hard for quasi-fiscal resources will have brought home to many the short-term nature of the fiscal gains to be made. In some cases the politicians who undermined the banking system have still been in power when its collapse presented them with what was only a slightly deferred bill. But short-termism is not likely to be completely eliminated by such experience, and one must seek stronger institutional arrangements within which governments and politicians are less likely to act in such a way as to generate financial collapse.

Effectively we are seeking a mechanism whereby governments can constrain themselves and their successors to avoid short-termism and abuses, thereby strengthening the hand of the national bank regulators. It is in this context that the establishment of an international sanction or seal of approval becomes desirable. 


\section{Annex \\ Early-warning indicators for the three syndromes}

\section{Choosing indicators}

This annex looks in more detail at the issue (discussed in Section III of the text) of choosing early-warning indicators which may point to weakness or vulnerability in the system.

It is not suggested that assessing whether a country's banking system is vulnerable to one of the main types of banking crisis is an easy job. Indeed, many authors have stressed that bank supervision is a highly skilled task learnt largely through on-the-job experience and not reducible to a few simple rules of thumb. Bank supervision specialists boast that the "apprenticeship" lasts ten years. Nevertheless, it is desirable to have some form of screening, attainable without the application of highly specialised skills, at an overall system level, which can help decide on which countries available surveillance resources should be focused for the best results.

Following the scheme proposed, we group the potential warning signals under the headings of macro-related epidemics, micro-only epidemics and endemic government-related problems, corresponding respectively to the three main syndromes discussed in the text.

\subsection{Macroeconomic epidemics}

The endogenous form of this type of crisis has fairly clear characteristics. Unusual asset price movements, rapid growth of lending especially for property transactions and for financing of stock market positions, capital inflows: these are some of the tell-tale signals of a credit-financed asset price boom which may prove to be unsustainable. We divide the indicators into two classes:

\subsubsection{Aggregate balance-sheet and operating account data suggesting unsound banking}

These are general indicators which apply whether or not there is a macroeconomic boom and bust cycle, and therefore also apply to syndrome 1.1.2 below. The idea here is that warning signs from individual banks' accounts that are used in industrial countries to flag banks that may be at risk can also be used at the aggregate level to flag systems at risk. Among the most promising series would be:

- One measuring aggregate balance-sheet change, namely the growth in aggregate lending (in real terms). This is the classic leading indicator of individual bank failure, and may also serve for systems. ${ }^{21}$

\footnotetext{
21 As is argued by Gavin and Hausman (1995).
} 
- Two drawn from the structure of the balance sheet, namely the loan-to-deposit ratio and reliance on foreign borrowing. Higher values of each suggest a banking system that may be overreaching its resources in more ways than merely financial. (On the other hand, very low values of the loan-to-deposit ratio may ${ }^{22}$ indicate a banking system whose managers choose, or are constrained, not to exploit their franchise.) Of course they are flags, not a conclusive indication of weakness. ${ }^{23}$ Foreign borrowing is also likely to involve foreign exchange risk for the system, directly or indirectly, unless this is swapped out in the international market.

- Two drawn from the operating accounts, namely the gross interest margin as a percentage of total assets and the share of non-interest income in total income. A low interest margin is suggestive of potential profit problems even if this indicator is prone to manipulation through the crediting of rolled-over interest. A high share of non-interest income is sometimes taken as indicative of potential weakness in core business, and potential overreliance on volatile or contestable sources of revenue. ${ }^{24}$

These aggregate balance-sheet data are already available from international sources, and we provide some evidence of their predictive performance below.

\subsubsection{Specific indicators for macro-cycles}

Specific indicators for this type of crisis may be drawn from information on the following three variables:

- The rate of growth of aggregate bank lending to the commercial property sector should be used as an indicator. ${ }^{25} \mathrm{~A}$ real rate of growth of $20 \%$ sustained over two years would be a warning sign.

- Prices of real estate property and of equities. Only the latter are readily available, but efforts should be made to develop series for residential and office prices. ${ }^{26}$ After deflation by a general price index or expressed in terms of US dollars, the gap between

22 As stressed by Rojas-Suarez and Weisbrod (1995).

23 In particular, some banks specialise in lending rather than deposits.

24 Although described above as available or potentially available, it has not been customary in many countries to prepare bank operating account statistics systematically on an aggregate basis. It should be, and the appropriate model for doing so is at hand in the form of the OECD Profitability of Banks series originally developed by Revell and published annually.

25 That this indicator must be used in conjunction with other information is well illustrated by the analysis of financial factors in growth by Johnston and Pazarbasioglu (1995), who show that credit expansion (and the level of interest rates) has quite opposite effects on future growth depending on whether or not the banking system experiences a crisis.

26 There are well-known technical problems in constructing such series, thinness of the markets and lack of homogeneity in traded properties being the most acute. 
the current price and a trend indicator (such as a moving five-year average) could be taken as an indicator of the downside risk in each of the markets.

- Aggregate inflows of portfolio capital totalling 10\% of GDP over a two-year period would also be a warning sign. (This in addition to the foreign indebtedness of the banking system mentioned above under 1.1.1.)

Although the warning signs are clear, their interpretation will be disputed. Nobody can be confident of knowing that a boom is unsustainable, or when the crash will occur. An equilibrium of cognitive dissonance can be envisaged: thus, given the resistance and scepticism with which proposals for corrective action will be met, those concerned with preventing crises will err on the side of predicting more crises than actually occur.

Despite the threshold values suggested above, it may be better not to have a common threshold value for these particular variables, but to base the threshold for each country on past experience for that country.

Finally, an additional source of information, not often readily available, but pointing to a direction in which data collection could be improved over time, is the increase in enterprise indebtedness as measured by the growth in leverage in a sample of enterprise accounts. Such a variable could contain some predictive power, as is evidenced by its use in a series of studies by Tybout (1986) and others of the Southern Cone crises of the early 1980s. There is a standard methodology for the preparation of aggregate financial accounts along the same lines (SNA 1993) but a small sample approach is more attainable.

\subsection{Poor management and other microeconomic deficiencies}

In examining the system for weakness under this heading, we want to know if the banks are financially sound, and whether they are being managed in a prudent manner by trustworthy persons. Possible sources of information include (i) publicly available (or potentially available) balance-sheet and operating account information, (ii) evidence of market confidence from interest rate structures and market performance, and (iii) regulatory information of two types: summaries of information available to the regulators and assessments of the quality of regulation itself. The ease with which this information can be obtained clearly varies, and some of it will not be obtainable in respect of some countries.

Because fraud and reckless behavior must be concealed if it is to be successful, it will be hard to find conclusive evidence before the damage has been done. Nevertheless, because it is the business of bankers to assess creditworthiness, it will frequently be observed that market rumors and loss of confidence in banks which have been involved in fraudulent or reckless behaviour often predate any clear evidence of their difficulties. Such banks may be excluded from borrowing on the 
interbank market, and may be paying higher interest rates on deposits for some time before collapse. Thus, of the three sources, we place most confidence in the second.

\subsubsection{Balance-sheet and operating account information}

This is essentially the same item as in 1.1 above.

\subsubsection{Market-based indicators}

Market participants are among the best-placed to know or suspect which of the system's institutions have problems. Their suspicions will partly be revealed by prices in, and the functioning of, the short-term money markets. ${ }^{27}$

We suggest three measures here. First, if a large proportion of the banks have no de facto access to the interbank market, or have access only at high rates, then this is a clear warning sign. This information is not normally published, but should be fairly readily available to any credible investigator.

Information about the rates being offered by different banks on large time deposits is also informative (and would, for example, have clearly flagged the Banco Latino in Venezuela months before it failed). Our second market measure is thus the interquartile spread on such interest rates. A high spread could suggest a liquidity scramble by banks in difficulty. In a low or moderate inflation economy an interquartile spread of as little as 200 basis points for comparable maturities and size could already indicate problems, though measurement errors in this type of data may mean that a wider spread would be needed before a warning flag is raised. Data on deposit rates are often collected on an informal basis by the Bankers' Association, or even by newspapers. This information should be collected by the central bank on a much more systematic basis than is common at present.

The third market measure, suggested by historical studies as well as by contemporary observation, is the gap between Treasury bill and large bank deposit (or CD) rates. This gap needs to be adjusted for the effects of any differences in the tax treatment (explicit or implicit) of Treasury bills and deposits in each particular country. After such adjustment it should provide a good measure of the market price of bank default risk.

\subsubsection{Regulatory information}

While we argue elsewhere that much of the information provided to regulators should also be publicly available on a bank-by-bank basis, this is not yet the situation in most countries.

27 For a few countries, commercial rating agencies such as IBCA are beginning to rate developing country banks. So far only a handful of countries are covered, but this is a supplementary information base whose coverage is likely to grow. 
Neverthelesss, some regulatory authorities are willing to share some aggregate information, and some, like Chile, do publish substantial detail (see Box).

The most useful kind of information for the outsider to have would be on loan loss experience and on the ratio of capital to risk-weighted assets. Even though banker optimism, or the desire to conceal the worst from regulators, means that the really large deteriorations in these indicators usually happen after the crisis is known to all, nevertheless small changes may be leading indicators of solvency problems. Accordingly, a rather low trigger value would seem appropriate here. Sheng's (1996) rule of thumb that a crisis is inevitable when non-performing assets exceed provisions by $15 \%$ of the total will not often yield an early warning, as such a level of non-performing assets is unlikely to be reported by a bank which is not widely known to be in distress. Instead, it is suggested that a reported increase in the stock of non-performing loans ${ }^{28}$ of as little as $2 \%$ of total loans should be seen as a matter for concern. A reported decline in the capital ratio of 0.5 percentage points would generate equal concern. ${ }^{29}$

Other more detailed types of regulatory information are less likely to be made available, and need specialist interpretation anyway. Besides, much of the regulatory structure is designed in such a way as to place prudent ceilings on various balance-sheet ratios (relating to such aspects as loan concentration, related lending and provisioning). To that extent, it is not so much the actual ratios as the adequacy of the regulatory requirements and their enforcement that needs to be verified.

As to the adequacy of the regulatory and supervisory system, with nearly all countries now sensitised to the need for a good system and general agreement on the main design elements of such a system, problems are most likely to arise in the form of delays in legislation, leaving regulators without the powers they require; weak enforcement and technical inadequacies either in the regulations or in the quality of supervision..$^{30}$ Although a detailed appraisal will not be possible without specialised assistance, especially in regard to the third item, and as such is beyond the scope of the present exercise, it may still be possible to detect potential problems by seeking the answers to three simple questions.

- First, what is the status of planned legislation in bank supervision and what is the nature of any delays encountered?

28 The definition of non-performing loans will vary from country to country. Typically, data will be available on the stock of loans on which interest or capital payments are more than 90 (or 180) days in arrears. The data should relate to the total value of the loans concerned, and not be limited (as was the case in Mexico) to the amount of the arrears. As mentioned, although arrears have the merit of being a fairly objective indicator, they are not the only criterion that regulators should be using in classifying loans as substandard, doubtful or loss.

29 Depending on provisioning practices, these two triggers would roughly correspond.

30 As exemplified in the circumvention, to which reference has already been made, of the limits on open foreign exchange positions in Mexico. 
- Second, who authorises waivers or exemptions to regulatory norms, and how frequent and widespread are such exemptions; are any banks in violation of regulatory norms without having received exemption?

- Third, has each significant bank been inspected on-site within the past two years?

If the regulatory authorities respond to such questions in an open manner, their answers will reveal much about the likely effectiveness of the regulatory system. The questions could easily be multiplied, but a discussion of these three with the authorities should capture the major dimensions of any deficiencies.

\subsection{Crisis in a government-permeated banking system}

Financial crises which are chiefly associated with government interference in the banking system are typically gradual affairs. Structural features which hint at the potential for problems of this type include:

- Government ownership of a large segment of the banking system is often a sign of problems to come, although as indicated, even the lending of private banks can be controlled by government.

- It is often possible to obtain data on the proportion of lending that is at the free discretion of banks, that is, not subject to compulsory deposits or sectoral allocations. The compulsory component may be made up of compulsory reserves held at the central bank or compulsory investment in government securities or lending to specified borrowers or to a fund whose disposition is not at the discretion of the bank. A compulsory component in excess of $25 \%$ would suggest a high degree of government involvement - though it may be noted that at end-1994 banks in 40 countries held central bank reserves in excess of that proportion of their deposit liabilities. Sectoral allocations usually come in the form of minimum proportions of the asset portfolio to be held in loans to certain broad categories such as agriculture, particular geographical regions or ethnic groups. In complicated regimes overlapping requirements may make the net free share of the portfolio difficult to specify. (For example if there were, say, a 30\% minimum share for agriculture and a $25 \%$ minimum share for a particular region, both might in principle be satisfied leaving $70 \%$ free, but achieving that extent of overlap might be impracticable for the banks.) If the bank has less than $50 \%$ of its portfolio freely disposable, then again the degree of government involvement is high. ${ }^{31}$ Note, however, that many countries operate a system of sectoral allocations which is hardly enforced, and therefore one

31 It is not suggested that requirements below the stated thresholds represent a desirable level from the point of view of efficiency. 
should not read too much into an ostensibly mandatory schedule of sectoral credit allocations. ${ }^{32}$

- Borrowing from the central bank often entails some degree of official control over the banks' use of the credit; this should be another indicator. Persistent borrowing equivalent to as much as $25 \%$ of deposits is a warning sign.

- The size of the budget deficit may help predict timing in that a deterioration here may trigger increased reliance on the banking system.

- The scale of implicit or explicit financial intermediation taxation ${ }^{33}$ is also an indicator of government reliance on the banking system; likewise a high level of government subsidy of the banking system ${ }^{34}$ may indicate that the system has fallen into a state of dependency, possibly as a result of previous government pressures. Measuring these requires some work, though methodologies have been developed and applied to many cases (see Chamley and Honohan (1990)).

Finally, there is a potential application here of some indicators of political risk. The political structures and traditions of a society will be an important additional influence on the vulnerability of the banking system to predation from political powers. Relevant dimensions would be the degree of concentration of political power in elite groups, ${ }^{35}$ the freedom of the press, ${ }^{36}$ and the autonomy of regional governments vis-à-vis the centre. ${ }^{37}$ In practice, political indicators may be constructed either through direct measurement of such political structures, or by drawing on one or other of the multipurpose political risk judgemental indicators marketed by commercial firms. ${ }^{38}$

\section{The structural indicators in practice}

In order to obtain some impression as to how structural indicators might perform in practice, we compiled data on a subset of the proposed variables for a selected sample of 24 countries.

32 Rojas-Suarez and Weisbrod (1995) use the size of bank reserves to some extent as a proxy for this variable, but with a somewhat broader interpretation of what it might be capturing.

33 This needs some calculation. The simplest approach is to calculate the additional spread in basis points on nonfavoured loans resulting from the need to break even on funds borrowed at opportunity cost equal to the Treasury bill rate (or interbank rate), assuming that all costs of reserve requirements and forced below-cost lending are to be recovered from non-favoured loans.

34 To be expressed as a percentage of total assets. One per cent would be high.

35 The more concentrated, the more prone the banking system may be to predation.

36 A free press and an informed public opinion being more likely to inhibit political abuse of the banking system.

37 This factor is included to take account of the externality, mentioned above, which regional governments have tended impose on the centre by exploiting regional banks to the point where they need to be rescued by the centre.

38 Such as the International Country Risk Guide (ICRG) or Business Environment Risk Intelligence (BERI). 
The countries were divided into four groups, six for each of the main crisis syndromes and a further six countries regarded as control cases. The assignment of countries is subjective, and the exercise is designed to see whether the proposed indicators would have flashed in advance for those countries which we now know to have had problems of the different types. The control group is based on a listing of countries in Lindgren, Garcia and Saal (1996), where no significant problem is reported for these countries; but the results do not hinge crucially on any assumption that the banking systems of these countries were exemplary.

In choosing the list, preference was given to developing countries, though in order to have clear-cut cases for the macro epidemics, two industrial countries have been included in that group (A), and in order not to rely on very small countries, two industrial countries were also included in the control group (D).

A time series on seven indicators was drawn from IMF's International Financial Statistics, corresponding to a selection of the indicators suggested above for epidemic ("ab") and government ("c") type crises. The epidemic indicators are the sub-group that serve for both the macro (a) and micro (b) varieties.

The indicators used are:

ab1 Loan-to-deposit ratio

ab2 Foreign borrowing: ratio to deposits

ab3 Growth rate of real bank credit

c1 Bank discretion over use of funds, measured by share of reserves to deposits

c2 Government share of lending

c3 Central bank refinancing of bank lending

c4 Government deficit

The countries chosen are:
A (macro)
B (micro)
C (government)
D (control)

Argentina 1980-1982

Colombia 1984-1985

Cameroon 1989-1995

Honduras

Chile 1981-1983

Kenya 1993-

Egypt 1991-

Switzerland

Mexico 1994

Malaysia 1985-1986

Hungary 1987-

Malawi

Uruguay 1982-1985

Nigeria 1991-1995

Pakistan 1980s

Morocco

Norway 1987-1993

Thailand 1983-1988

Philippines 1981-1987

Portugal

Sweden 1990-1993

Venezuela 1994

Poland 1991-

Syria 
We find that, comparing the average values of these indicators as for the different groups, the performance is sharply different as between the different country groups. ${ }^{39}$ All three "ab" indicators correctly flag the "A" countries. Three of the "c" indicators correctly flag the "C" countries. Conversely, only one of the "c" indicators flags the "A" countries, and none of the "ab" indicators flags the " $\mathrm{C}$ " countries. This confirms the diverse nature of crises, and the need to tailor one's indicators to the type of structural weakness likely to be present.

Something of a disappointment is the inability of the "ab" indicators to flag the "B" countries. As it happens, most of the B countries chosen are countries whose crises were relatively small in magnitude, probably explaining why this particular subset of indicators, based as it is on aggregate data, is not very effective in the context. Other indicators mentioned above for micro crises would have more chance of picking up relatively small crises.

Table

Mean value of selected indicators for sample countries

\begin{tabular}{|l|c|c|c|c|c|c|c|}
\hline \multirow{2}{*}{$\begin{array}{c}\text { Country } \\
\text { group }\end{array}$} & \multicolumn{7}{|c|}{ Indicator } \\
\cline { 2 - 8 } & $\mathrm{ab} 1$ & $\mathrm{ab} 2$ & $\mathrm{ab} 3$ & $\mathrm{c} 1$ & $\mathrm{c} 2$ & $\mathrm{c} 3$ & $\mathrm{c} 4$ \\
\hline $\mathrm{A}$ & $116.9^{* *}$ & $31.5^{*}$ & $10.1^{* *}$ & 21.6 & 18.2 & 21.2 & -2.8 \\
$\mathrm{~A}-3 \mathrm{y}^{1}$ & $121.1^{* *}$ & 25.4 & $22.2^{* *}$ & 19.6 & 13.5 & 12.5 & 0.2 \\
& & & & & & & \\
B & 92.0 & 9.1 & 5.7 & 15.9 & 16.4 & 3.4 & -3.3 \\
B - 3y & 90.9 & 9.5 & 1.9 & 16.8 & 16.5 & 5.4 & -5.5 \\
C & 85.5 & 18.4 & $7.8^{*}$ & $24.8^{*}$ & $35.9 * *$ & $25.2^{* *}$ & -3.7 \\
C - 3y & 84.3 & 20.8 & 5.7 & 20.7 & $34.9 *$ & $21.6^{* *}$ & -3.0 \\
D & 82.7 & 20.5 & 4.0 & 15.7 & 24.4 & 9.1 & -5.0 \\
\hline
\end{tabular}

${ }^{1}$ Mean of indicator for three years before date given for start of crisis.

Asterisks denote indicator significantly larger for this country group than for group D, variance assumed known and equal to sample variance for all 24 countries.

$* *=95 \%$ confidence.

$*=80 \%$ confidence.

39 Our methodology here is quite simple. The value of the indicator is computed for each country, both the mean for 1975-94, and the mean for the three years before the starting date given for that country's crisis, if any. These means are then averaged over the countries in the group. A pairwise comparison is then made between the mean for group D and that of each of groups $\mathrm{A}, \mathrm{B}$ and $\mathrm{C}$ respectively. The differences, shown in the table, lead to the clear-cut conclusions reported in the text, despite the small sample size of six countries per group. 


\section{Box: Disclosure in practice - Chile}

The monthly report "Financial Information" published by the Chilean Superintendency of Banks and Financial Institutions provides a useful blueprint for what should be contained in a disclosure document. This report, which appears within three months of the date to which the statistics refer, contains both aggregate and bank-by-bank information under four main categories. Data for each bank are given in the same format.

First, the monthly balance sheet, with considerable breakdown, for example as between short-term and long-term loans and up to a dozen categories of long-term loans. Overall, 63 asset sub-categories and 69 liability sub-categories are separately identified.

Second, the income and expenditure account, also very detailed, for example showing separately the interest paid to depositors in three maturity brackets and distinguished as between floating and fixed interest rate deposits. Altogether 47 sub-categories of income and 71 of expenditure are separately identified.

Third, liquidity, including a maturity analysis of each bank's gross positions in local and foreign currency in eight maturity classes and distinguishing between fixed and floating interest rate items. Required and actual liquidity balances.

Fourth, an analysis of debtors, including size distribution (number of debtors in each of 11 size categories), size of lending to related borrowers (distinguishing between production companies, investment companies and individuals), estimated required provisions and actual, the bank's own classification of loan portfolio by quality, and the Superintendency's most recent assessment of the quality of the bank's loan classification procedures.

Information is also provided inter alia about changes in major shareholdings and directors, and about the condition of financial affiliates of each bank. 


\section{References}

Akerlof, G. and P. Romer (1993), "Looting: The Economic Underworld of Bankruptcy for Profit", Brookings Papers on Economic Activity, No. 2, pp. 1-73.

Arrow, K.J. (1982), "Risk Perception and Psychology in Economics", Economic Inquiry, 20, pp. 1-9.

Bank for International Settlements (1996), 66th Annual Report.

Boot, A.W. and A.V. Thakor (1993), "Self-Interested Bank Regulation", American Economic Review Papers and Proceedings, Vol. 83, pp. 206-212.

Borish, M.S., M.F. Long and M. Noel (1995), Restructuring Banks and Enterprises: Recent Lessons from Transition Countries, World Bank Discussion Paper 279 (Washington, DC).

Caprio, J.G., Jr., D. Folkerts-Landau and T.D. Lane, eds. (1994), Building Sound Finance in Emerging Market Economies (Washington: IMF and World Bank).

Caprio, J.G., Jr. and D. Klingebiel (1996), "Bank Insolvency: Bad Luck, Bad Policy or Bad Banking?", Presented to the World Bank Annual Conference on Development Economics.

Chamley, C. and P. Honohan (1990), "Taxation of Financial Intermediation: Measurement Principles and Application to Five African Countries", World Bank Policy Research Working Paper 421.

Claessens, S. (1996), "Banking Reform in Transition Countries", Background Paper for the 1996 World Development Report, mimeo.

Davis, E.P. (1992), Debt, Financial Fragility and Systemic Risk, (Oxford University Press).

de Juan, A. (1995), "The Roots of Banking Crises: Micro-economic Issues and Issues of Supervision and Regulation", Presented to the IADB/G-30 Conference on Banking Crises in Latin America Washington, DC, 6th-7th October 1995.

Dewatripont, M. and J. Tirole (1994), The Prudential Regulation of Banks (Cambridge, MA: MIT Press).

Diaz-Alejandro, C. (1983), "Goodbye Financial Repression, Hello Financial Crash", Journal of Development Economics, 19, pp. 1-24.

Garber, P.M. (1995), "Managing Risks to Financial Markets from Volatile Capital Flows: The Role of Prudential Regulation", Conference Paper.

Gavin, M. and R. Hausman (1995), "The Roots of Banking Crises: The Macroeconomic Context" presented at the Conference on Banking Crises in Latin America, Washington, DC, October 1995.

Guttentag, J.M. and R.J. Herring (1986), "Disaster Myopia in International Banking", Princeton Essays in International Finance, No. 164, September 1986. 
Honohan, P. and D. Vittas (1996), "Bank Regulation and the Network Paradigm: Policy Implications for Developing and Transition Economies", The World Bank Policy Research Working Paper 1631.

Johnston, R.B. and C. Pazarbasioglu (1995), "Linkages Between Financial Variables, Financial Sector Reform and Economic Growth and Efficiency", IMF WP/95/103.

Kane, E.J. (1995), "Difficulties of Transferring Risk-Based Capital Requirements to Developing Countries", Pacific-Basin Finance Journal, 3, pp. 193-216.

Lindgren, C., G. Garcia and M. Saal (1996), Bank Soundness and Macroeconomic Policy, IMF, forthcoming.

Padoa-Schioppa, T. (1996), "Address to the 9th International Conference of Banking Supervisors", Stockholm.

Rojas-Suarez L. and S.B. Weisbrod (1995), Financial Fragilities in Latin America, IMF Occasional Paper.

Sheng, A., ed. (1996), Bank Restructuring (Washington, DC: The World Bank).

Tenconi, R. (1988), "Restructuring of the Banking System in Guinea", World Bank, mimeo.

Tybout, J. (1986), "A Firm-level Chronicle of Financial Crises in the Southern Cone", Journal of Development Economics, 24, pp. 371-400.

Vittas, D. (1992), Financial Regulation: Changing the Rules of the Game (Washington, DC: The World Bank). 



\section{Recent BIS Working Papers}

No.

24

April 1995

25

April 1995

26

April 1995

27

May 1995

28

August 1995

29

September 1995

30

November 1995

31

December 1995

32

December 1995

33

January 1996

34

January 1996

35

July 1996

36

August 1996

37

September 1996

38

October 1996
The structure of credit to the non-government sector and the transmission mechanism of monetary policy: a cross-country comparison

A survey of non-financial sector balance sheets in industrialised countries: implications for the monetary policy transmission mechanism

The monetary transmission mechanism: evidence from the G-7 countries

The response of short-term bank lending rates to policy rates: a cross-country perspective

The term structure of Euro-rates: some evidence in support of the expectations hypothesis

The information content of the term structure: evidence for Germany

Money demand stability and currency substitution in six European countries (1980-1992)

Testing the quantity theory using long-run averaged cross-country data

The anatomy of the bond market turbulence of 1994

Derivatives and asset price volatility: a test using variance ratios

Monetary policy and the behaviour of interest rates: are long rates excessively volatile?

Varieties of monetary policy operating procedures: balancing monetary objectives with market efficiency

Estimation of speculative attack models: Mexico yet again

Does the term structure predict recessions?

The international evidence

International agreements in the area of banking and finance: accomplishments and outstanding issues
Claudio E.V. Borio

John T. Kneeshaw

Stefan Gerlach and Frank Smets

Claudio E.V. Borio and Wilhelm Fritz

Stefan Gerlach and Frank Smets

Stefan Gerlach

Renato Filosa

Stefan Gerlach

Claudio E.V. Borio

Robert N. McCauley

Benjamin H. Cohen

Stefan Gerlach

Joseph Bisignano

William R. Melick

Henri Bernard and Stefan Gerlach

William R. White 


ISSN 1020-0959 